\title{
SELF-LOVE AND SELF-ACCEPTANCE: REDEFINING IDEAL BEAUTY THROUGH ITS REPRESENTATION IN SCARS TO YOUR BEAUTIFUL
}

\author{
Ida Rosida and Dinni Yulia Saputri \\ Universitas Islam Negeri Syarif Hidayatullah Jakarta \\ email: idarosida@uinjkt.ac.id
}

\begin{abstract}
The ideal beauty has a significant impact on social life. Those who feel that their body does not meet the idealized body view might have body dissatisfaction and low selfappreciation. This study is aimed at exploring a broader definition and understanding of beauty as it is represented in Scars to Your Beautiful, a song by Alessia Cara, from both its lyric and music video. Using content analysis and supported by the concept of the figures of speech, cinematography, and representation by Stuart Hall investigation on this beauty ideal is completed. Results show that Scars to Your Beautiful strives to redefine the term of beauty which cannot be determined only by certain criteria such as having a thin body, white skin, flawless and addressed to women only, but beauty also reaches a broader definition in all shapes size, color, and even gender. These findings highlight the importance of self-love and self-acceptance in the social context.
\end{abstract}

Keywords: beauty ideal, representation of beauty, body dissatisfaction

\section{CINTA DAN PENERIMAAN DIRI: REDEFINISI KECANTIKAN IDEAL YANG DIREPRESENTASIKAN DALAM LIRIK LAGU SCARS TO YOUR BEAUTIFUL}

\begin{abstract}
Abstrak
Kecantikan ideal memiliki dampak penting dalam kehidupan sosial yakni adanya ketidakpuasan terhadap tubuh dan berkurangnya penghargaan terhadap diri sendiri. Kajian ini mengeksplorasi definisi dan pemahaman cantik yang lebih luas sebagaimana direpresentasikan dalam lirik lagu dan video musik Scar to Your Beautiful oleh Alessia Cara. Metode penelitian yang digunakan adalah konten analisis didukung dengan konsep figurative language, cinematography, dan konsep representasi Stuart Hall. Hasil penelitian menunjukkan bahwa Scars To Your Beautiful mencoba mendefinisikan kembali kata cantik yang tidak hanya ditujukan bagi mereka yang memiliki tubuh langsing, kulit putih, tidak ada gores luka pada tubuh, dan hanya ditujukan pada perempuan, melainkan cantik ini memiliki definisi lebih luas yakni pada semua bentuk tubuh, semua ukuran tubuh, dan semua warna kulit, termasuk gender. Hasil penelitian ini menegaskan kembali pentingnya mencintai dan menerima diri dalam konteks kehidupan sosial.
\end{abstract}

Kata Kunci: kecantikan ideal, representasi kecantikan, ketidakpuasan terhadap tubuh 


\section{INTRODUCTION}

Beauty is a term that has a variety of definitions and is very subjective. Beauty may initially be seen as the physical, such as shape and form, but it also could equally be about its function and effects on people, and the environment one has inspired (Yung 2017:5). However, most people usually associate this term only with someone's physical appearance when in fact, this term also applies to the nature or character within a person. The reason is that beautiful physique enhances one's social worth. Moreover, people with attractive physique are more likely to be successful both socially and economically (Kuipers 2015:38). For people, particularly women, the perceptions of self-worth are based partly on their physical appearance, including their body shape and body weight (Betz et al. 2019:100). A slim body is very desirable for most women in the world today. The women beauty ideals continue to glorify the thin ideal that represents the female form as a slender, feminine physique with small waist and little body fat (Robinson et al 2017:65). For these reasons, people continue to compete to have the ideal beauty.

A slender, small waist, feminine body has predominated as the Western cultural ideal for decades, and standardization of this thin ideal is linked to body dissatisfaction and self-objectification (Betz et al. 2019:100). One of the biggest factors regarding is that people continue to be bombarded by information in the mass media that transmits and strengthens values and norms, fashion and beauty ideals through models, movie stars, and female celebrities in various media formats (Yan Yan \& Kim Bissell
2014:194). The excessive of beauty ideal emphasized on the media industry is not only a phenomenon found in western countries, but it has become a more global problem (Yan Yan \& Kim Bissell 2014:195). Although often unrealistic and unattainable, these beauty ideals transmitted through various sociocultural channels and have been internalized by women and even young girls. (Rice et al. 2016:4).

In the past decade, research on body image has increased and has generated knowledge gathered about various components and expressions (Tracy L. Tylka \& Amy C. Iannantuono 2016:1). Until now, this topic is still one of the most interesting topics to be discussed by using different methods, theories, and different social context. The current research on beauty ideal was conducted by Diana E Betz, Sabik, and Ramsey (2019) entitled Ideal Comparison: Body Ideals Harms Women's Body Image Through Social Comparison. This article discusses the beauty ideal using the theory of psychology namely social comparison which is revealed that state and traits social comparison has a function in social relation. Next, the research of Robyn L. Moffit, Neumann, and Williamson (2018) entitled Comparing the Efficacy of a Brief Self-Esteem and Self Compassion Intervention for State Body Dissatisfaction and Self-Improvement. This research explored the efficacy of writing task for reducing body dissatisfaction using the psychological approach. These two researches focus their study relate to body images seen from psychological approach. Then, research by Alan Robert and Sena Muta (2017) entitled 
Representations of Female Body Weight in the Media: An Update of Playboy Magazine from 2000 to 2014 that reviewed changes in women's body size represented in Playboy magazine from 2000 to 2014. This research shows that the representation of body image represented in Playboy magazine is getting more real based on the models' body mass index.

Based on those three previous researches, it is obvious that the discussion of beauty ideal seems never end. Further, this research is aimed at exploring how the beauty ideal is also represented in literary work such as song lyrics and music video. Apart from the rise of mass media that describes the beauty ideals that are too unrealistic, there are also many artists and celebrities who try to criticize this beauty ideal through their works or simply voice their opinions on social media and utilize their existence to invite women to love their bodies. A singer who voiced beauty ideals is Alessia Cara in her song Scars to Your Beautiful. The song is talking about the current situation in western society particularly on how people especially women keep glorifying the unrealistic beauty ideals. The music video features people of all ages, genders, ethnicities, and backgrounds simply show its models taking turn talking about their experience or personal struggle that they have had to overcome and share their thoughts regarding the beauty ideals. Each of them is representing themselves as the real definition of beauty in all shapes, sizes, and colors along with all their scars, flaws, imperfections, and differences.

Analyzing Alessia Cara's Scars to Your Beautiful lyric and music video is important as it is represented the broader definition of ideal beauty. Further, the song represents the real situation that happened in the world regarding body ideals that leads to body dissatisfaction. This occurs when the body's weight and shape are undesirable and beyond expectation (Moffitt et al. 2018:67). This issue of body-dissatisfaction is known to leads to depression, eating disorder, or even suicidal thoughts as the effect of beauty ideals, and it has become a real matter and a global problem. Therefore, interventions to reduce body dissatisfaction have long been considered an important research priority (Moffitt 2018:67).

The used of representation theory by Stuart Hall particularly constructionist approach, supported by figure of speech and cinematography, it allows the researcher to reconstruct meaning of beauty and finally could redefine the meaning of beauty through its representation in lyric and music video. Further, this research will become a new view about beauty ideals as it is represented in Scars to your beautiful. Additionally, Scars to Your Beautiful won the MTV Music Video Award in the United States in 2016, for the music video with the best social message. This award strengthens how important it is to analyze the representation of beauty as it is presented in the song lyrics and its music video.

\section{METHOD}

This research utilizes qualitative content analysis as the method of the research since this research relies on text and image data. Qualitative content 
analysis can be defined as an empirical approach, methodological controlled analysis of texts within their context of communication, following content analytical rules and step-by-step models, without rash quantification (Mayring 2004). The instrument used in this research is the writers themselves as the subject of the study to collect the data, reading the lyric comprehensively, making notes, and analyze the corpus. The unit of analysis that will be used in this research is in the form of words, phrases, and sentences in the song lyric, and in the form of physical depictions contained in audio-visual media, namely the music video by Alessia Cara entitled Scars to Your Beautiful. This song was written by Alessia Cara, Warren "Oak" Felder, Coleridge Tillman, Andrew "Pop" Wansel, and DJ Frank E with production handled by Felder, Tillman, Frank E and, Wansel.

The theories used in this research are the representation by Stuart Hall using the constructionist approach by which the users of language could improve the meaning of language or reconstruct meaning (Hall,1997). Next, the literary theory consists of figures of speech and imagery to analyze the lyric (Perrine,1992) and the cinematography concept by Barsam and Monahan's book (2015) which will investigate the music video. The technique of data analysis is conducted by collecting the data; the process is reading the song lyric line by line, and by watching the music video comprehensively. The data then classified into two; first, how beauty is represented in the song lyric using the concept of figures of speech. Second, how beauty is represented in the music video using the concept of cinematography. Both are analyzed based on the concept of representation by Stuart Hall. Further, how beauty is represented in the lyrics and its music video then reveal the broader definition of beauty ideal.

\section{RESULTS AND DISCUSSION \\ Results}

The analysis shows three main results: First, beauty, based on Scars to Your Beautiful, is defined as a quality within every single human being that worth more than just physical attributes. The song is representing people in all range of ages, genders, shapes, sizes, and colors to redefine the real definition of the term beauty which cannot be determined only by a certain physical criteria such as age, gender, body size, body shape, skin color, or as known as the beauty ideals. Second, Scars to Your Beautiful is representing critics on beauty standards that have been built by the society and widely spread by most media. Third, Scars to Your Beautiful is representing the act of self-love and self-acceptance to encourage all the audience to do so. Based on the totality of the song, there are no certain criteria to be beautiful. Being different and having scars as part of someone's imperfection is actually the uniqueness that makes every single human being beautiful, and finally, the inner-quality is all that matters.

\section{Discussion}

\section{The Representation of Beauty in Lyrics}

In the first discussion, the lyric will be analyzed stanza per stanza to find out the meaning and the idea in it. The figurative language which includes figures of 
speech and imagery are also identified, interpreted, and analyzed to find out how the song lyric represents the term beauty.

\section{She just wants to be beautiful}

She goes unnoticed, she knows no limits

She craves attention, she praises an image

She prays to be sculpted by the sculptor

From the first stanza, the speaker uses the pronoun she to indicate that this song is directed to women, especially women who feel unsatisfied with their body, the women who feel insecure, and most women are often feeling that way. The repetition of the word she in the first four lines of the lyric emphasizes the meaning that the main focus of this song is for women. Even though the speaker uses the word she to make it sounds like the song is only directed to women, the music video says something different about it. The music video tries to say that even when the main focus of the song is women, men and even transgender can also relate to this idealized or standardized beauty ideal as well.

Starting the first stanza, the speaker gives a clue about what is going on with a clear statement that stands for the current situation of women nowadays with all the beauty standards that make them feel like they were nothing, and worthless. The speaker then gives some more information about the situation where women are often to feel unsatisfied about their body; they crave for attention. "She praises an image", an image here refers to the beauty ideals that have been built by the society through all the mass media, an image of how women are supposed to look, and women are dying to look this certain way so that they can be considered as beautiful. "She prays to be sculpted by the sculptor" means they are also hoping that they can be physically shaped to be more ideal, or literally means wishing to be born with a better physical appearance.

This first stanza is describing the situation to the audience in which body dissatisfaction is the issue that is going on in today's society and sooner or later will harm these unsatisfied people physically and mentally. Beyond its role as target intervention, both thinness-oriented and muscularly-oriented body dissatisfaction also plays a huge role as the risk factors for developing eating disorder and even depression, as well as decreased wellbeing, such as lower life satisfaction, selfesteem, self-compassion, optimism, secure attachment, and proactive coping (Karazsia et al. 2017:294).

Oh, she don't see the light that's shining

Deeper than the eyes can find it

Maybe we have made her blind

So she tries to cover up her pain

And cut her woes away

'Cause covergirls don't cry

After their face is made

The word light in the second stanza "She don't see the light that shining" is a symbol which refers to the inner quality within people, but they cannot even see it. "Deeper than the eyes can find it" means that these inner attributes cannot be seen through the eyes because these women are too busy focusing on their physical attributes, it is not something physical, it is something deeper than that. This inner attribute is for example, their personality, their attitude, their heart, 
their manner, and their way of thinking. It is not surprising that most women internalize the message about how important the physical beauty is, because they have been given these pervasive cultural messages and they come to believe that their worth as a person is based on their physical attributes (Homan and Tylka 2015:2). So, when they do not have this physical beauty, they started to feel like they do not worth it. These pervasive cultural messages about the importance of physical beauty are one of the things that make women blind about their worth and inner beauty. "Maybe we have made her blind" is a hyperbole since the word blind here does not carry the literal meaning of blind, but it refers to the situation where the current society (we) tends to bombard women with some certain criteria that are too unrealistic and it makes women "blind" about the fact that the real beauty comes from within and not only from the physical appearance. The last four lines in the second stanza indicates how women tend to cover up their pain and cut their woes away, because these cover girls never cry after their face is made which means that they were born to be physically ideal, and these unsatisfied women are trying to be one, by trying so hard to conceal their scars and all of their imperfections.

But there's a hope that's waiting for you in
the dark
You should know you're beautiful just the
way you are
And you don't have to change a thing
The world could change its heart
No scars to your beautiful
We're stars and we're beautiful

But there's a hope that's waiting for you in the dark

You should know you're beautiful just the way you are

No scars to your beautiful
Entering the refrain of the song, the lyric starts with "There's a hope that's waiting for you in the dark", there is a personification in this line describes how hope, which is an abstract concept described as something alive and waiting in the dark. It means that there is hope for us to change and redefine our perception of beauty that has been missleaded by the media. The next line, again, is identifying another personification where the world is described as something alive that could change its heart. The word world here refers to society: how the society could possibly change their perception of beauty ideals which probably no longer limited only to some certain shapes, sizes, and colors. The stanza ended with a clear statement "No scars to your beautiful", the word scars here is a symbol that stands for an imperfection, it means that it does not matter how many scars or imperfection we have, we are all still beautiful and will always be, and "we're stars and we're beautiful", we're stars here is a metaphor, we refers to all human beings in general, with all shapes, sizes, and colors, emphasizes the meaning that everyone is shining like a star and every single human being is beautiful.

We have seen that over time, people are starting to realize that these beauty standards are not realistic. The media is also starting to promote the diversity of people in color or more realistic body shapes. One example brought out by one of the beauty company, Dove, which has been working on to further the global understanding of women, beauty and well-being, and the relationship between them. They are also working on to assess 
whether it is possible to talk about women beauty in a way that is more authentic, satisfying, and empowering. Dove set out to change the definition of beauty as portrayed by the media and turn beauty into a source of confidence and not of anxiety (Amaral 2017:3). This is what is meant by "the world could change its heart" even though it is still in a very small amount of change, but for sure, there is hope.

\section{She has dreams to be an envy, so she's starving You know, "Covergirls eat nothing." \\ She says, "Beauty is pain and there's beauty in everything." \\ "What's a little bit of hunger?" \\ "I can go a little while longer," she fades away.}

The fourth stanza describes more about women's insecurities, this stanza is emphasizing one of the body ideals that have been shaped in the society, which is a skinny body or in other words, the skinnier they look, the more beautiful they are. The word covergirl is a synecdoche since it describes a part that is made to represent the whole, refers to the mass media in general that often represents how women should look like through their models. Advertising and the media in general are regularly criticized for the way they represented women, particularly the use of young women as the models, the continuing of stereotypes, demeaning women, being sexually suggestive, and depicting unrealistic body images. These images can also harm women as they start to compare and try to reach these unattainable beauty ideals set by the media. That effect includes low selfesteem, depression, eating disorders, exercise addictions, unhealthy attitudes toward sex, sexuality and body image, and even can lead to suicide (Waller 2015:109).

The word she in this stanza refers to women who are willing to be starving so they can be as skinny as the cover girls who "eat nothing" which is a hyperbole to express how skinny cover girls are as if they eat nothing. There is another visual imagery here as we can imagine in our head that most of the cover girls nowadays are very skinny. A little bit of hunger means nothing because as they said "Beauty is pain" so they will keep going a little longer and longer to starve. Beauty is pain is a metaphor; means that it requires pain to be beautiful, so they need to sacrifice a little to get the ideal shape of beauty standardized by society. These women are always having these thoughts in their mind "What's a little bit of hunger? I can go a little while longer" so they keep starving to get the ideal body that they want, and "she fades away" refers to how they are not even realizing that they actually torturing themselves and keep living their lives as if nothing happened and this is the effect of the unrealistic beauty standards that have been mentioned above.

She don't see her perfect

She don't understand she's worth it

Or that beauty goes deeper than the surface

Ah, oh, ah, ah oh

The fifth stanza is where the speaker says that these women do not even realize 
that they are perfect and worth it, they started to forget their inner beauty attributes that they own deep in their heart as in "Or that beauty goes deeper than the surface", and they are too busy paying attention only to their physical flaws which are in the surface, their physics. These women are often focusing so much on superficial beauty that they fail to appreciate the exceptional power of the inner beauty (Nahai 2018:1040). All the beauty ideals are making these internal beauty goes even deeper, it means that the society is turning these women into someone else and not themselves because these women wanted to be as ideal as possible to the world.

Clearly, this stanza shows that most women are ignoring the fact that they are worth it. They are not appreciating themselves the way in which they supposed to be, especially since body appreciation is what stops these women from accepting the unattainable and unrealistic beauty ideals. This lack of body appreciation is one of the factors that make these women feel less and always comparing anyone else's body to theirs which then leads them to face body dissatisfaction issues.

So to all the girls that's hurting

Let me be your mirror

Help you see a little bit clearer

The light that shines within

In the sixth stanza, the speaker is offering herself to be 'the mirror' of these insecure girls, the girls who are hurting. The mirror here is a metaphor which means that me, who is the speaker, will be helping these women through the music
'Scars to Your Beautiful' to help them realize and see the real definition of beauty, which is something that shines from within and it has nothing to do with physical appearance. The word light in "the light that shines within" again, is a symbol stands for inner quality within everyone. The speaker hopes that the song can be the reflection of how every human being should see themselves as a perfect creature, appreciate themselves, love themselves more, and not letting the scars or imperfection lessen their selfworth. They need to pay more attention to their inner attributes because their physical appearance means nothing if they do not have this inner beauty.

The song lyric represents the idea how the society has shaped and standardized the ideal beauty since it can lessen how much we love and appreciate ourselves and this is the time to change our old way of thinking regarding beauty ideals. The lyric is representing the term beauty as something that is not limited to some certain criteria; beauty is not merely about physical appearance. The most important attribute that makes people beautiful is their inner quality, and the scars in the song means the imperfection, which is what makes everyone unique and beautiful.

\section{The Representation of Beauty in Music Video}

In the second discussion, the music video will be analyzed using the concept of cinematography to find out how it represents the term beauty. The music video started with the appearance of Alessia Cara, the singer of the song, with her face without any makeup, her natural curly hair, wearing a simple black long 
sleeves shirt and simple black pair of jeans.

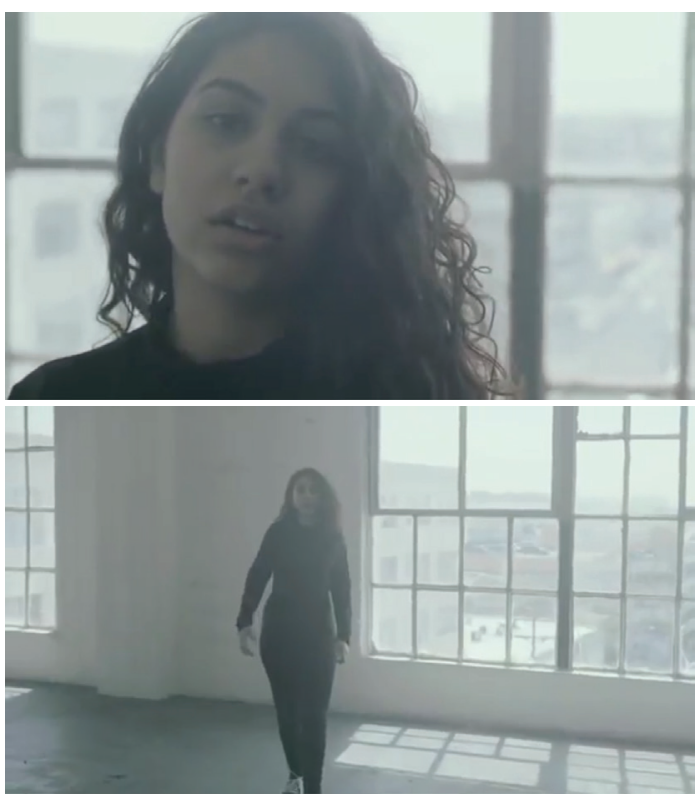

Picture 1 and 2. Alessia Cara looking natural in an empty room

This is the first scene and she looks very natural in an empty room with some huge windows in her background. The lighting used in this scene is natural lights where Alessia Cara is standing in an empty room with some huge windows right behind her and the windows give so much natural sun light into the room. The lighting seems to softly diffused, and clearly, they do not need to add more artificial lighting in such room of this kind and in the day light. The quality for this scene's lighting is high-key, since the lighting is soft, spreading, and created a low-contrast outcome. This type of lighting clearly fits the scene and succeeded in bringing up and supporting the concept the music video which is simplicity and reality.

In the second scene, there are some women and men from all range of ages introducing their names as Jess, Carmel, Francesca, Miles, Myreen, Marney, Florence, Shavon, Joanna, Christina, Josh, Kylie, Miranda, Joad, Grace, James, and Tasha. There is one familiar face shows up here in the music video, who is Joanna or known as JoJo who is a public figure. From here, we can see that the music video is trying to reach out to all of the audience that even a public figure has insecurities as well.

From the introduction, the audience can clearly see that these people are very diverse, physically. All of the models in this music video look very realistic, this is the real people, the real body, and is clearly contradicting all the beauty standards that the mass media is usually presented. When asked about women's body ideals in today's western culture, most people described a similar woman image. The ideal woman is a model, according to western social and cultural standards. She has to be tall, tanned, thin, has large breasts, clear skin, and is often has long blond hair-many of the same features that researchers and critics blame for women's low self-esteem and unrealistic expectation because so few women has those physical attributes (Millard 2009:154). At this point, we can see that the concept of this music video is the realistic image of people in all shapes, sizes, and colors; and criticizing beauty standards at the same time.

The song then continued and from this part of the music video, the lyric synchronized the clip very well as the lyric goes "Deeper than the eyes can find it", the camera then goes to shot Shavon's eyes; 


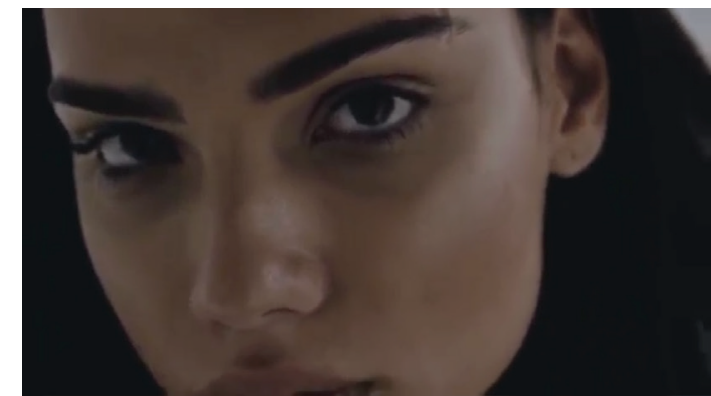

Picture 3. Shavon's eyes looking straight to the camera

"So she tries to cover up her pain, and cut her woes away"", the camera goes to Carmel, the woman who wears headcover;

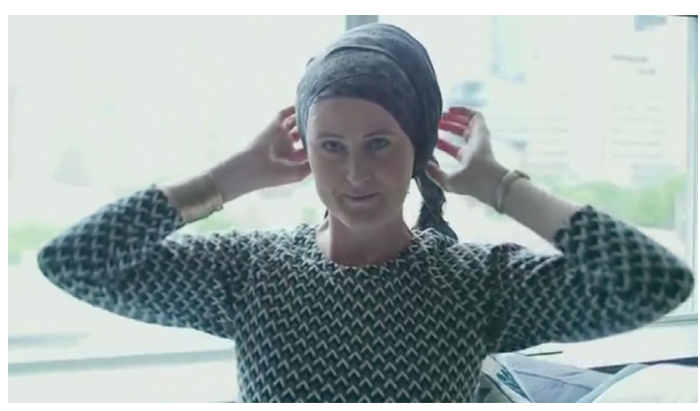

Picture 4. Carmel with a head-cover

"Cause cover girls don't cry", the camera showing Shavon's full-body sitting on the chair as if she's in the middle of a photo shoot session;

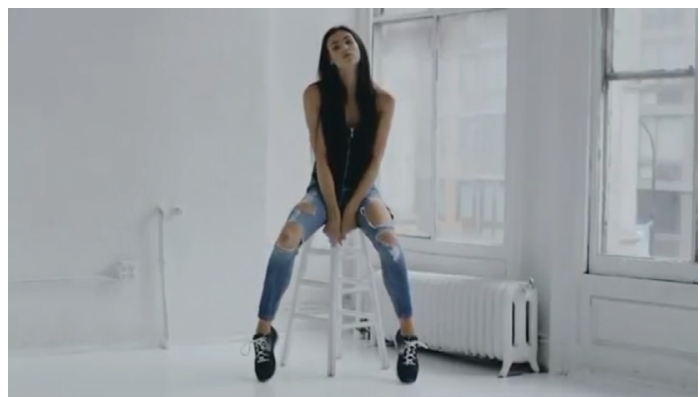

Picture 5. Shavon posing like a cover girl
"After their face is made", the camera then goes to Joanna while she is covering up her face with her hands.

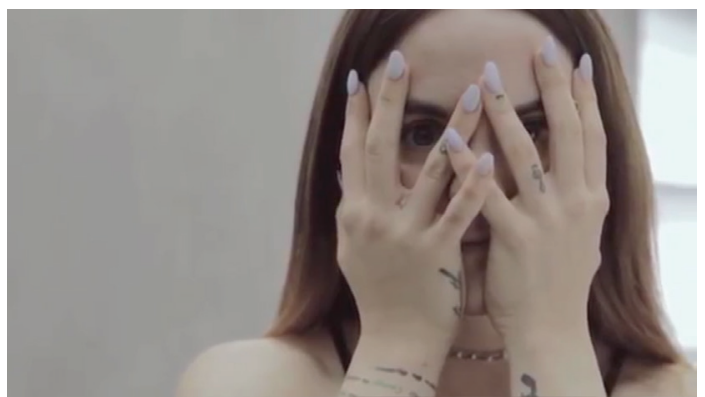

Picture 6. Joana covering up her face with her hand

This synchronized shot is giving a certain emotion to the viewer and connect the lyric with the video very well, giving the perfect image in the viewers' mind. Entering the refrain of the song, the first image is showing an overweight woman standing at the corner of the balcony.

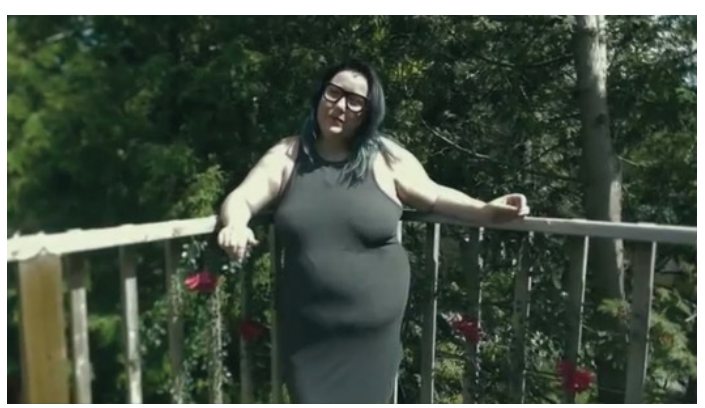

Picture 7. An overweight woman standing in the balcony

This woman is not one of those people who introduced themselves earlier, and she represents the beauty in all sizes. As stated in Affull and Ricciardelli's, we live in a culture of negative collective "knowingness" of fat women, where they are known to be lazy, 
lacking willpower, and sexually out of control (2015:3), and through this music video, Alessia Cara wants to change that "knowingness" and represents the form of beauty in all sizes.

The next person is Miles, the camera then does the extreme close-up to one of his un-perfect ear, represents beauty in all shapes where one of his ears can be considered as an imperfection or what the lyric is symbolized with the word "scars". This type of shot points out some great details carried by the models; most of those details are the scars or the imperfection of the models. In this scene, the camera is trying to points out one of Miles' ear that looks 'imperfect'. From this length of shot, the audience can clearly see Miles' imperfect ear, and also this shot was taken to emphasize the meaning that any kinds of imperfection will never lessen someone's worth. As already mentioned above, Miles is the representation of beauty in all shapes.

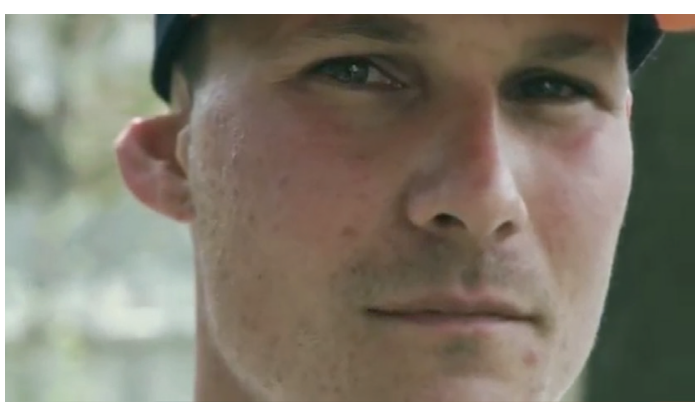

Picture 8. Miles with his un-perfect ear

Next, the camera goes to Grace, a woman with slanted eyes smiling, another representation of beauty in all shapes where there is a beauty criteria that described round eyes as one of the attributes for the ideal beauty, along with narrow faces and pronounced noses (Yan
Yan \& Kim Bissell 2014:197). The next scenes are showing some of the models sharing their thoughts and experience, their expression captured perfectly, as Mayreen says "there are my peers, and then there was me", initiating the insecurities she feels when she's around her friends, she makes some kind of border between herself and her friends because she thinks she's not as pretty as her friends. Then, Joanna says "and a lot of people aren't afraid to give their opinions whether they're hurtful or not", represents the current society that is very judgmental and seems to not really care about the way they give their opinion.

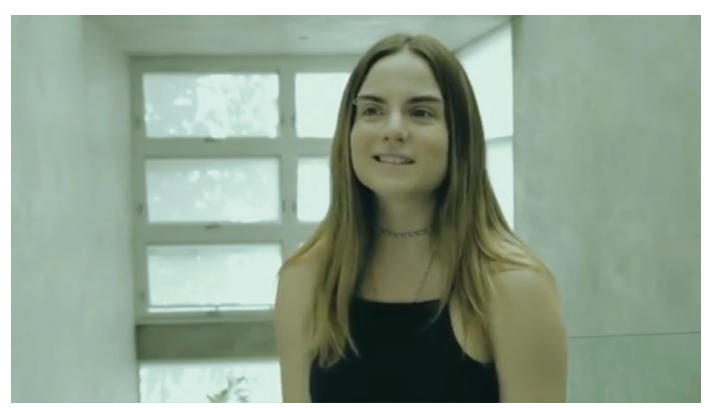

Picture 9. Joanna sharing her thoughts

This medium close-up shot gives a certain effect to its audience in which it catches the models' expression even in the slightest changes and their body gesture. Furthermore, the concept of the music video is trying to show the real experience of its models, and their gestures are captured perfectly from this length of shot. This kind of shot can be seen when the camera catches Joanna's expression when she is sharing her experience about how people can easily speaking out their opinion without thinking that it may hurtful or not. Then, Kylie says "people would laugh and stare 
(at her)" because she is a cancer survivor who lose her hair from medical therapy such as chemo, this is also representing how the society can be so cruel to someone who physically different such as Kylie.

An overweight woman says "people watching you eat and making little comments", another experience that represents the current situation of society that always tends to judge something only based on physical appearance. Francesca says "As I grew up thinking that I had to look a certain way", represents the stereotypes and perception built by the society that even already exist and planted since we were kids. Francesca has an athletic body with muscles that is more identic with men's body and this is another representation of beauty in all shapes. Many kinds of research showed that the pervasive body ideals in popular culture are unattainable for most healthy human beings, even though, many people still adopt these ideals as their personal goals. Individuals who internalize these societal and cultural influences often experience body dissatisfaction (Karazsia et al. 2017:295). This is what makes most people want to change their physical appearance when they actually do not need to and the music video coherence the lyric as the lyric later goes "you don't have to change a thing, the world could change its heart".

Christina, the Asian woman, says "I never thought I was as pretty as the other girls", again, represents the insecurities women tend to feel growing up in a society where physical appearance seems to be the number one aspects of the ideal beauty. Then Miles says "be proud, I shouldn't be trying to hide it" represents the way people are supposed to act, to be proud of who they are and not to be ashamed by their flaws. Women still frequently engage in comparing themselves to the idealized beauty criteria even when these are unnecessary and affect them in negative self-evaluations. Experimental findings have shown that exposure to beauty ideals raises comparison based on physical appearance, with the extent of comparison predicting increased weightrelated thoughts, anxiety, negative mood, and body dissatisfaction (Mulgrew 2017:127).

The camera then starts doing close-up shot where the camera photographed the models from their chest up to their head and emphasizing the models' expression even better. In this scene, the camera does the close-up shot on Miranda while she is looking down the scars on her chest, then, the camera moves up and shoots her smiling face. This camera movement and her attitude represent the power of self-acceptance. This kind of shot gives the viewer a certain emotion showing that even when we have scars, whether it is a visible or invisible scar, we are still beautiful if we accept it as a part of ourselves.

Then, there is a transgender woman shows up after, represents other shapes of beauty. The appearance of other gender than women in this music video is clearly stating that the term beauty is not only applied to women, even when the lyric of the song is directed to women, Alessia Cara is also want to make the audience see other effects of beauty ideals on other gender from her music video. Beauty 

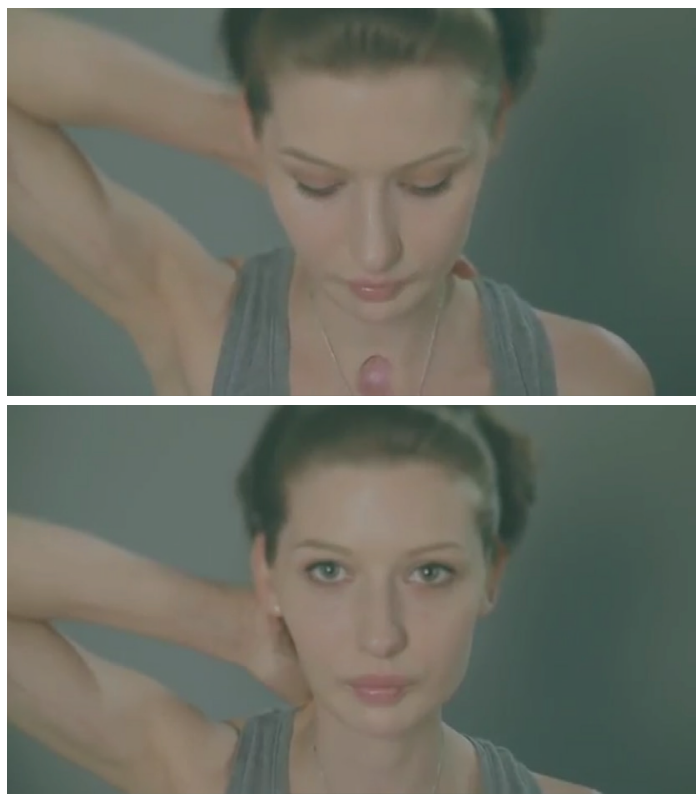

Picture 10 and 11. A woman looking down to her hole scar on her neck then looking straight to the camera

ideals have affected people in all gender as well, and from the music video, she wants to define a new definition of beauty which is not only quality a women can have, but beauty is about all the human beings and there is no gender limitation when it comes to the term beauty.

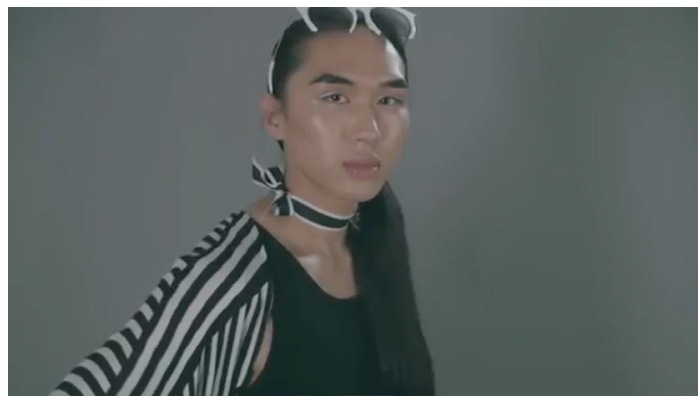

Picture 12. A transgender who represents beauty in all shape

If we consider beauty as something that give back a sense of harmony and familiarity within a person, then for certain subjects, the incompleteness of their body is deeply associated with the idea of 'strangeness' that often stands for 'ugliness'. For many transsexuals, their original body is not perceived as 'familiar' for them, but on the contrary, their original body is their source of anomaly (Mauriello 2017:57). The main point that Alessia Cara wants to emphasize here is not how this transgender woman change her appearance to look beautiful, but she changed the way she looks to be her true self, and that is what the real beauty is; to be the true self of ours. And we, as human beings, should never judge any other person only based on their appearance, because beauty is not merely about that, beauty is about being what's in our deepest heart.

The next part of the music video is another sharing session of thoughts and experience as an overweight woman says "it's been something I've struggled with my entire life, not feeling like I fit in", this represents the struggle of women who have the same body dissatisfaction issues as her, especially there is much evidence that one characteristic of beauty ideal as represented by the media, is extreme thinness. Given some certain body shape and weight as the ideal body such as thin, small waist, and minimal body fat is unrealistic and unachievable for most women (Moffitt 2018:68). As we previously have seen that this specific issue of body weight has been one of the focus of the song lyric as well.

The music video then entering the stage of confidential and realization of self-love as Mayreen says "hold on and just wait until you can get out of that bubble, because the things that seem like 
weaknesses, that seems like weird things that make you strange, when you become an adult and get out into the world, you're gonna find out that all those differences, they're like your greatest strengths", a very powerful message to encourage everyone to consider their flaws and differences as their greatest strength and not as their weakness because by the time they grew up they will soon realize that life is not merely about physical appearance, life is more about being who we truly are and living our best life is the only option we have at the end of the day. While Mayreen says that, the music video is showing and trying to emphasize the other models' flaws and their uniqueness. This illustrates the lyric very well because the message of the lyric itself is generally talking about the real meaning of beauty which is not limited only to some certain criteria and that every single human being is beautiful.

The camera then does an extreme close-up shot to a tattoo of the words Hope and Faith which somehow carry a related message of self-love, a woman with a hole scars in her neck, Carmel open up her head-cover, and some more new models expressing their confidence through their big smiles. These scenes show that the models have reached the self-compassion stage, which defined as an attitude of kindness and understanding toward their dissatisfaction and struggles including three interconnected components which are mindfulness, selfkindness, and common humanity (Homan and Tylka 2015:2).

Tasha says "a lot of it was in my own head I realize now", represents that most of these insecurities are actually came from ourselves, indirectly trying to tell the audience to start loving and fully accept ourselves first. Josh says "there's always someone that's unique now, which is what the cool part and that's what made me comfortable to realize that every single person is different", represents more of self-confidence and self-love. Every human being is unique with their differences and flaws, it is a part of them and it doesn't lessen our selfworth. Followed by Joad says "personality outshines everything else at the end of the day", this is one of the strongest message that the music video is trying to deliver, that personality is all that matters and our physical appearance should never take our confidence away because the true meaning of beauty shines from within.

Christina says "what only matters is what I think of myself and that everyone has different kinds of beauty", another message that we should never let the way other people think of ourselves affect the way we see ourselves, and that everyone is beautiful with their own kinds of beauty. Another woman who is not a part of those introducing their names then says "smile, smile" with her beautiful smile, also followed by all the models smiling and shining their confidence self out.

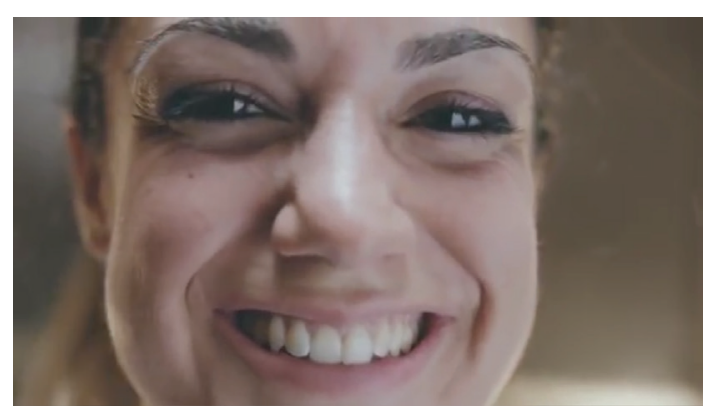

Picture 13. Francesca smiling to the camera 


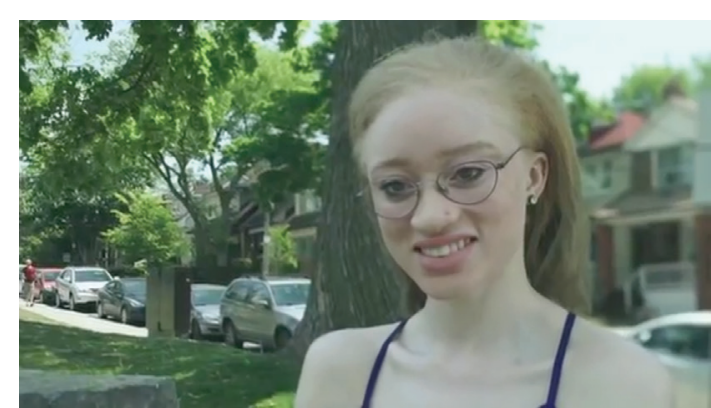

Picture 14. Myreen smiling to the camera

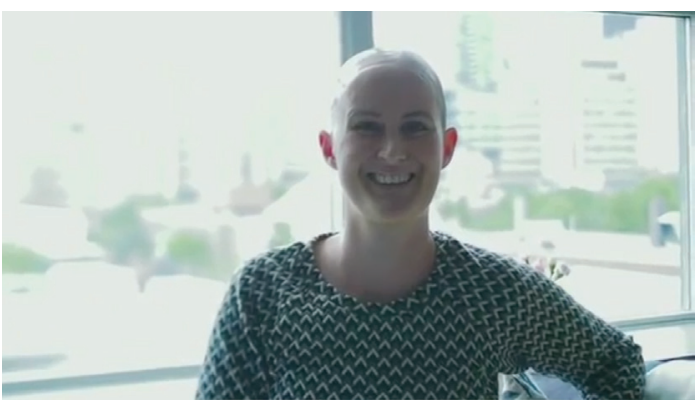

Picture 15. Carmel smiling to the camera

These scenes are also coherence with the song lyric because, from the lyric, the speaker wants the audience to love themselves more and to realize that the inner beauty is all that matters to outshine the real definition of beauty. Most of the camera angle used in the music video is eye-level shot which implies that the subject being photographed is neutral. The concept of the music video itself is about sharing moments of real life experience by the models, so this kind of camera angle shot is the most neutral and suitable to be used.

As we can see, the models of the music video are dominated by women because women typically engage in a stronger orientation towards appearance than man, and express more negative attitudes about their physical appearance (Mulgrew 2017:126). Yet, the appearance of other gender which is men and even transgender is emphasizing the term beauty as a quality that is not only applied to women. This gives the audience a picture of how the beauty ideals have impacted not only women, and from the music video, Alessia Cara wants to remind people that beauty ideals have affected human beings in general. The message at the end of the music video clearly stating the purpose of the music video itself which is to remind everyone that beauty is in an endless amount of forms and everyone needs to recognize that. Especially, for the past three decades, the pervasive portrayal of beauty ideals in popular media has been a critical societal concern as exposure to these ideals is expected to relate to suffering from mental health disorders such as depression (Vandenbosch 2017:3). So, through this music video, hopefully, the speaker can spread the awareness to love and appreciate themselves more, to stop chasing for any kind of beauty ideals, and to start changing the toxic perspective of beauty ideals itself. Millard added on his work that the real beauty comes from various shapes and sizes, along with its flaws, and is the key to rebranding, rebuilding women's self-esteem, and redefining beauty standards (2009:146). It means that everyone is beautiful without any exception and we have to aware of that. Through this music video, the speaker wants the audience to realize that it's time for all of us to give this broad understanding of real beauty to the world by starting to be confident and accept ourselves first, fully and truly.

To sums up, both lyric and the music video of Scars to Your Beautiful along with its narration are criticizing the unrealistic 
beauty ideals that have been built in our society. The song in general is representing the term beauty as something that is not limited to a certain age, gender, body shape, body size, or body color. Beauty based on this song is a quality that comes from within, the inner attributes. Beauty can be obtained starting from a state of mind that makes people realize that they are worth it. Most people still do not realizing this and the song is trying to deliver the message of self-love and selfacceptance so that the audience can stop criticizing on the way they look physically and start focusing on their inner beauty because at the end of the time, that is the only thing that matters. The other important points that the song is trying to deliver is that the imperfection or what is here symbolized as scars is actually what makes everyone unique and beautiful, and we need to accept it as a part of ourselves and to not consider these scars as something that lessen our beauty.

\section{CONCLUSION}

The song is trying to urge the audience to love themselves more, to be their true self, and to pay more attention to their internal attribute within themselves. The music video illustrates the lyric since it represents the same meaning and the same idea of the song lyric, even when the lyric is directing the song to women, the music video is representing models from all different gender: women, men, and transgender. It emphasizes the term beauty which is universal and not only addressed to women. The gender diversity in this music video is also a representation of how the beauty ideals have affected other gender as well in defining beauty.
The music video adopted the concept of simplicity and reality. All the models participated in the music video are physically diverse from one another; they are from different range of ages, genders, background, ethnicity, body sizes, body shapes, and skin colors along with their flaws whether it is visible or invisible scars and every one of the models represents their own kinds of beauty. Moreover, both the lyric and the music video of Scars to Your Beautiful are critics on the ideal beauty in today's society which often promoted a certain physical criterion to define the term beauty that often unattainable and unrealistic. Finally, beauty is a quality that every human being has, and it can be obtained starting from a state of mind that makes people believes in the quality and the worth of themselves.

\section{ACKNOWLEDGEMENT}

The writers would like to express their gratitude to UIN Syarif Hidayatullah Jakarta particularly English Literature Department for supporting this research.

\section{REFERENCES}

Afful, A. A., \& Ricciardelli, R. (2015). Shaping The Online Fat Acceptance Movement: Talking About Body Image and Beauty Standards. Journal of Gender Studies, 24(4), 453-472. doi. org/10.1080/09589236.2015.10285 23.

Alessia, C. (2016). Lyrics to Scars to Your Beautiful. AZLyrics. https://www. azlyrics.com/lyrics/alessiacara/ scarstoyourbeautiful.html.

AlessiaCaraVEVO. Alessia Cara - Scars to Your Beautiful. Online video clip. 
Youtube. Youtube, 11 July 2016. Web. 28 November 2018.

Amaral, A. C. (2017). Dove Real Beauty Campaign: A Local Perspective(Doctoral Dissertation).

Barsam, R., \& Monahan, D. (2015). Looking at movies. WW Norton \& Company.

Betz, D. E., Sabik, N. J., \& Ramsey, L. R. (2019). Ideal Comparisons: Body Ideals Harm Women's Body Image Through Social Comparison. Body image, 29, 100-109. doi.org/10.1016/ j.bodyim.2019.03.004

DiYanni, R. (2004). Literature: Approaches To Fiction, Poetry, and Drama. McGraw-Hill.

Hall, S. (Ed.). (1997). Representation: Cultural Representations and Signifying Practices (Vol. 2). Sage.

Homan, K. J., \& Tylka, T. L. (2015). Selfcompassion Moderates Body Comparison and Appearance SelfWorth's Inverse Relationships With Body Appreciation. Body image, 15, 1-7. doi.org/10.1016/j.bodyim. 2015.04.007

Karazsia, B. T., Murnen, S. K., \& Tylka, T. L. (2017). Is Body Dissatisfaction Changing Across Time? A CrossTemporal Meta-Analysis. Psychological bulletin, 143(3), 293. doi.org/10.1037/ bu10000081

Kuipers, G. (2015). Beauty and Distinction? The Evaluation of Appearance and Cultural Capital in Five European Countries. Poetics, 53, 38-51. doi.org/10.1016/j.poetic. 2015.10.001

Mayring, P. (2004). Qualitative Content analysis. A Companion to Qualitative Research, 1, 159-176.
Mauriello, M. (2017). What the Body Tells Us: Transgender Strategies, Beauty, and Self-consciousness. In Talking Bodies (pp. 55-73). Palgrave Macmillan, Cham. doi.org/10. 1007/978-3-319-63778-5_4

Millard, J. (2009). Performing Beauty: Dove's "Real Beauty" Campaign. Symbolic Interaction, 32 (2), 146-168. doi.org/10.1525/si. 2009.32.2.146

Moffitt, R. L., Neumann, D. L., \& Williamson, S. P. (2018). Comparing the Efficacy of a Brief Self-Esteem and Self-Compassion Intervention for State Body Dissatisfaction and Self-Improvement Motivation. Body Image, 27, 67-76. doi:10.1016/j. bodyim.2018.08.008

Mulgrew, K. E., Stalley, N. L., \& Tiggemann, M. (2017). Positive Appearance and Functionality Reflections Can Improve Body Satisfaction But Do Not Protect Against Idealised Media Exposure. Body Image, 23, 126-134. doi.org/10.1016/j.bodyim. 2017.09.002,

Nahai, Foad. (2018). The Power of Beauty. Aesthetic Surgery Journal. 38(9), 1039-1041. doi.org/10.1093/ asj/sjy038.

Perrine, L, and R. Thomas. (1992). "ARP." Sound and Sense.

Rice, K., Prichard, I., Tiggemann, M., \& Slater, A. (2016). Exposure to Barbie: Effects on Thin-Ideal Internalisation, Body Esteem, and Body Dissatisfaction Among Young Girls. Body Image, 19, 142-149. doi. org/10.1016/j.bodyim.2016.09.005. 
Roberts, A., \& Muta, S. (2017). Representations of Female Body Weight in The Media: an Update of Playboy Magazine From 2000 To 2014. Body Image, 20, 16-19. doi. org/10.1016/j.bodyim.2016.08.009.

Robinson, L., Prichard, I., Nikolaidis, A., Drummond, C., Drummond, M., \&amp; Tiggemann, M. (2017). Idealised Media Images: The Effect of Fitspiration Imagery on Body Satisfaction and Exercise Behaviour. Body Image, 22, 6571. doi: $10.1016 / \mathrm{j}$. bodyim.2017.06.001.

Rosida, I. (2018). Tubuh Perempuan dalam Budaya Konsumen: Antara Kesenangan Diri, Status Sosial, dan Nilai Patriarki. Jurnal Antropologi: Isu-Isu Sosial Budaya, 20(1), 85-101. doi.org/10.25077/jantro.v20. n1.p85-101.2018.

Tylka, Tracy L., and Amy C. Iannantuono. (2016). "Perceiving beauty in all women: Psychometric evaluation of the Broad Conceptualization of Beauty Scale." Body Image 17, 67-81. doi. org/10.1016/j.bodyim.2016.02.005.
Vandenbosch, L. P. (2017). "Media Representation: Health and Body Images." The International Encyclopedia of Media Effects, 1-13. doi. org/10.1002/9781118783764. wbieme 0145 .

Waller, David S. (2015). "Photoshop and Deceptive Advertising: An Analysis of Blog Comments." Studies in Media and Communication 3.1, 109-116. doi. org/10.11114/smc.v3i1.841.

Yan, Yan, and Kim Bissell. (2014). The Globalization of Beauty: How is Ideal Beauty Influenced by Globally Published Fashion and beauty Magazines? Journal of Intercultural Communication Research 43.3, 194214. doi.org/10.1080/17475759.201 4.917432 .

Yung, S. (2017). What is Beauty in STEM, and How Can We Inspire This Feeling of Beauty in Students? Journal for Activist Science and Technology Education, 8(1). jps. library.utoronto.ca/index.php/ j a s t e / a r t i c 1 e / download/29145/21696. 